Pilarczyk, M., Woźniak, M. (2019). Pomoc publiczna na innowacje społeczne w Unii Europejskiej - perspektywa makroekonomiczna. W: N. Laurisz, A. Stronczek (red.). Ekonomia Społeczna. Innowacje społeczne (s. 51-58).

Kraków: Uniwersytet Ekonomiczny w Krakowie. https://doi.org/10.15678/ES.2019.1.06

\title{
Pomoc publiczna na innowacje społeczne w Unii Europejskiej - perspektywa makroekonomiczna
}

\author{
Magdalena Pilarczyk, Maciej Woźniak
}

\begin{abstract}
Streszczenie: Innowacje społeczne mają zaspokajać potrzeby społeczeństwa. Stanowią zatem jeden z elementów rozwoju społeczno-gospodarczego. Celem rozdziału jest analiza inicjatyw finansowanych z pomocy publicznej, przeznaczonych na innowacje społeczne w Unii Europejskiej. Autorzy przeprowadzili badania literatury przedmiotu oraz analizy istniejących rozwiązań z wykorzystaniem metody desk research. Ustalono, iż zagadnienia innowacji społecznych są coraz częściej tematem badań naukowych, jak też przedmiotem zainteresowania decydentów. Znajduje to swoje odbicie w działaniach instytucji unijnych. Zakres oraz wartość programów mających na celu wspieranie takich innowacji są bowiem coraz większe. Rozdział stanowi wkład w obszar polityki gospodarczej, w części poświęconej pomocy publicznej, jak również poszerza zakres literatury przedmiotu badającej tematykę innowacji społecznych.
\end{abstract}

Słowa kluczowe: innowacje społeczne; pomoc publiczna; Unia Europejska

Kody JEL: $\quad H 19, \mathrm{H} 39, \mathrm{O} 35$

\section{Wprowadzenie}

Za główne czynniki wzrostu gospodarczego przyjmuje się kapitał fizyczny, ludzki oraz postęp technologiczny. Ten ostatni wiąże się z innowacjami, które obejmują nie tylko nowe metody produkcji, lecz również rozwiązania mające na celu zaspokajanie potrzeb społeczeństwa. Tym samym wchodzą w zakres szerszego pojęcia, jakim jest rozwój gospodarczy. Koncepcja zawodności rynku wskazuje jednak na potrzebę wspierania ww. inicjatyw. Polska jako członek Unii Europejskiej (UE), również uczestniczy w opracowaniu takich rozwiązań w ramach tej organizacji. W związku z powyższym celem rozdziału jest analiza inicjatyw finansowanych z pomocy publicznej, przeznaczonych na innowacje społeczne w Unii Europejskiej.

Jego realizacja została przeprowadzona według określonego schematu. Najpierw przeprowadzono badania literatury przedmiotu dotyczącej zagadnienia innowacji, w tym innowacji społecznych. W dalszej części autorzy dokonali analizy istniejących rozwiązań z wykorzystaniem metody desk research. Na końcu rozdziału zawarto wnioski, ograniczenia oraz dalsze kierunki badań. 


\section{Przegląd literatury}

Termin innowacja pochodzi od łacińskiego słowa innovare, co oznacza odnowienie (Wasiluk, 2002, s. 335). Słownik języka polskiego PWN określa przytoczony termin jako „wprowadzenie czegoś nowego". Innowacje utożsamia się często z nowoczesnymi przedsiębiorstwami oraz nowatorskimi towarami i usługami. Od dawna podkreśla się ich rolę w rozwoju firm, na ogół przypisując ten termin szeroko pojętym technologiom. Nie są one jednak dziś wyłącznie przedmiotem analiz ekonomicznych, ale również obiektem zainteresowania szeroko pojętych nauk społecznych. Pojęcie innowacji wprowadził do literatury ekonomicznej austriacki ekonomista J.A. Schumpeter, odnosząc je głównie do technologii oraz wpływu na procesy gospodarcze (Górka, 2015, s. 32). Genezy powstawania innowacji nie utożsamiał bezpośrednio ze spontanicznie pojawiającymi się potrzebami wśród konsumentów, naprzeciw których wychodzą przedsiębiorstwa, lecz z reguły jako swego rodzaju taktykę przedsiębiorców, którzy mają powodować wśród potencjalnych nabywców potrzebę wykorzystania odmiennych sposobów na zaspokajanie potrzeb. Produkowanie nowych rzeczy bądź stosowanie innych niż dotychczas metod nazwał „kombinowaniem" materiałów i sił do tego niezbędnych, a tworzenie innych kombinacji rozwojem. Według jego wizji rozwój gospodarczy jest napędzany przez innowacje przedsiębiorstw, które mają charakter działań nieciągłych i skokowych.

Według myśli Schumpetera (1960, s. 104-106) innowacje odnoszą się do następujących przypadków:

- wprowadzenia nowego towaru lub jego ulepszenie,

- użycia nowej metody produkcji,

- otwarcia nowego rynku,

- utworzenia i wprowadzenia nowej organizacji przemysłu,

- zdobycia nowych źródeł surowców i półfabrykatów.

Pomimo że definicja ta została przez ekonomistę sformułowana w 1912 roku, obecnie wciąż uznawana jest za jedną z zasadniczych w literaturze. Poświęcił on zresztą obszerną część swoich badań tematowi innowacji, będąc autorem m.in. teorii rozwoju gospodarczego czy koncepcji twórczej destrukcji (Maślak, 2002, s. 225).

A. Olejniczuk-Merta, na podstawie analizy wniosków Schumpetera oraz innych badaczy, zdefiniowała innowację jako „każdą celową i świadomą zmianę na nowe”. Za cechy innowacji wyróżniła jej występowanie w określonych warunkach przestrzennych i czasowych, formę (materialną lub niematerialną), wynik nierutynowej działalności, powiązanie z wysiłkiem i ryzykiem oraz bezpośredni lub pośredni związek z człowiekiem i społeczeństwem jako odbiorcą końcowym (Olejniczuk-Merta, 2013, s. 22-23).

Bezpośrednio z istnieniem ostatniej z wymienionych cech wiążą się innowacje społeczne. L. Bałoń (2015, s. 4-5) definiuje je zatem jako „wdrożone projekty, których celem jest powstanie zmiany społecznej, w konsekwencji czego następuje wzrost dobrostanu społeczeństwa (poziomu i jakości życia) oraz tworzenie nowych form relacji międzyludzkich, prowadzących do: zapobiegania dezintegracji społecznej, wzrostu demokratyzacji życia oraz wzmocnienia kapitału społecznego".

Autorka wyróżniła ich podział według trzech kryteriów. Pierwszym z nich jest ich zasięg: makro, mezo oraz mikro. Skala makro i mezo dotyczy ich występowania w ramach aktów prawnych na różnych poziomach władzy samorządowej. Zasięg mikro odnosi się do obecności tego rodzaju innowacji w ramach jednostek takich jak przedsiębiorstwa, zarówno tradycyjne, jak i społeczne, czy podmioty non-profit. Drugim kryterium jest rodzaj beneficjentów innowa- 
cji społecznych. Jeżeli potrzebują oni pomocy bezpośredniej, innowacje społeczne stanowią w tym przypadku źródło wsparcia w formie materialnej bądź niematerialnej. Beneficjentami mogą być również osoby wyrażające potrzebę udoskonalenia sfery społecznej. Ostatnie kryterium dotyczy dziedzin aktywności ludzkiej. Mogą dotyczyć one szerokiego kręgu zainteresowań, przykładowo kultury, edukacji, administracji publicznej czy polityki (Bałoń, 2015, s. 4-5).

Podsumowując należy stwierdzić, iż tematyka innowacji jest już od dość dawna przedmiotem badań ekonomistów. Jednakże w ostatnim okresie daje się zauważyć coraz większe zainteresowanie obszarem innowacji społecznych. Dla potrzeb niniejszego opracowania zostały one zdefiniowane jako zmiany, które mają pozytywnie oddziaływać na całe społeczeństwo lub też jego część, często przez realizację oddolnych działań na poziomie lokalnym.

\section{Metoda badawcza}

Autorzy postanowili zastosować metodę desk research nazywaną również analizą danych zastanych lub „badaniem zza biurka”. Polega ona na wykorzystaniu informacji pochodzących z już istniejących publikacji. Na tej podstawie można sformułować wnioski odnośnie konkretnego problemu badawczego. Jak wskazuje Z. Bednarowska $(2015$, s. 19) metoda ta ma trzy główne zalety:

- większa dostępność oraz niższe koszty niż przeprowadzenie badań ilościowych czy też jakościowych,

- możliwość analizy na większych próbach,

- brak wpływu badacza na przedmiot badania.

Pamiętać jednak należy również o ograniczeniach tej metody. Należą do nich m.in. problemy wynikające z łączenia danych z różnych źródeł, które mogą mieć inne ramy czasowe, czy w odmienny sposób definiować pewne pojęcia. Ponadto nie ma możliwości weryfikacji rzetelności zbierania danych pierwotnych. W przypadku niniejszego opracowania autorzy uznali jednak, iż przedstawione wcześniej zalety są wystarczającą przesłanką do zastosowania metody desk research.

\section{Prezentacja wyników badania i ich omówienie}

Wspólnota Europejska stoi obecnie przed szeregiem wyzwań społeczno-ekonomicznych. Do ich przezwyciężenia konieczne jest zaangażowanie obywateli, organizacji pozarządowych, sektora publicznego i prywatnego, a również ich współpraca owocująca tworzeniem dobra wspólnego. Istotne są również innowacje społeczne. Często stymulują bowiem powstawanie nowych procesów gospodarczych i polityk, co jest niezwykle doceniane w Unii Europejskiej. Z tego powodu instytucje UE stworzyły bogatą ofertę wsparcia mającą na celu budowanie społeczeństwa obywatelskiego.

Jednym z pierwszych działań, które wyraźnie wskazywało na istotność innowacji społecznych była inicjatywa EQUAL, finansowana z Europejskiego Funduszu Społecznego. Obowiązywała w latach 2001-2006 i miała na celu zwalczanie dyskryminacji i nierówności zatrudnienia. Podkreślała szczególną rolę współpracy pomiędzy państwami członkowskimi oraz podmiotami sektora publicznego i prywatnego, w celu opracowania nowatorskich rozwiązań we wspomnianym zakresie. Wskazywała również na istotną rolę organizacji pozarządowych, stanowiących pewnego rodzaju pomost pomiędzy tymi dwoma sektorami, w rozwiązywaniu problemów społecznych. Środki w ramach inicjatywy przeznaczono m.in. na wspieranie dia- 
logu społecznego, rozwój podmiotów non-profit - trzeciego sektora gospodarki, a również pogłębianie podejścia typu good governance (Commission of the European Communities, 2003). Działania te objęły również Polskę, która rozpoczęła swoje uczestnictwo w programie przystępując do Wspólnoty Europejskiej w 2004 roku.

Kluczowym programem, wyznaczającym ramy obecnych działań UE, jest Europa 2020, którego celami przewodnimi są: inteligentny, zrównoważony i sprzyjający włączeniu społecznemu rozwój. Jedną z inicjatyw jest Unia innowacji. Ma ona tworzyć rozwiązania sprzyjające rozwojowi innowacji poprzez tworzenie warunków do pogłębiania wiedzy i badań, zmniejszanie dysproporcji pomiędzy obywatelami, finansowanie innowacyjnych produktów i usług oraz rozwojowi partnerstwa w procesie tworzenia innowacji, ze szczególnym uwzględnieniem innowacji społecznych (Komisja Europejska, 2014c). Obejmuje ona różnorodne możliwości wspierania takiej działalności, jak też powstawania i promowania nowatorskich rozwiązań, z uwzględnieniem inicjatyw, które mogą sprostać obecnym wyzwaniom społecznym. W tym celu wykorzystywane są środki głównie z Europejskiego Funduszu Społecznego oraz Europejskiego Funduszu Rozwoju Regionalnego.

Program Horizon 2020, ustanowiony przez Komisję Europejską, to największy pod względem wartości instrument, mający na celu finansowanie i wspieranie rozwoju badań i innowacji (Komisja Europejska, 2014b). Jedną z podstawowych motywacji do jego utworzenia jest unijne dążenie do osiągnięcia poziomu 3\% PKB na finansowanie badań naukowych i rozwoju na terenie Wspólnoty do 2020 r. Na jego realizację przewidziano ponad $77028 \mathrm{mln}$ euro (Rozporządzenie Parlamentu Europejskiego i Rady (UE) nr 1291/2013). Składa się on z trzech wzajemnie uzupełniających się priorytetów: doskonała baza naukowa (24441 mln euro), wiodąca pozycja w przemyśle (17016 mln euro) i wyzwania społeczne (29679 mln euro).

Pierwszy z wymienionych priorytetów ma na celu wspieranie wybitnych badaczy w rozwoju ich ścieżki zawodowej. Zwrócono w nim szczególną uwagę na wsparcie pionierskich badań mogących prowadzić do istotnych odkryć i wynalazków (finansowanych przez Europejską Radę ds. Badań Naukowych), dostęp do szkoleń, kursów i staży (działania Marii Skłodowskiej-Curie) czy tworzenie okazji do pozyskania odpowiedniej infrastruktury dla realizacji przedsięwzięć badawczo-naukowych (Komisja Europejska, 2014b).

Priorytet drugi ma wpływać na zwiększanie poziomu wykorzystania nakładów inwestycyjnych w przedsiębiorstwach, podkreślając ich znaczący wpływ na powstawanie różnego rodzaju innowacji, w tym innowacji społecznych. Szczególną uwagę skupia się tutaj na sektorze małych i średnich przedsiębiorstw, który to wymaga szczególnej pomocy z uwagi na utrudniony dostęp do finansowania swojej działalności oraz prac badawczo-rozwojowych.

Wyzwania społeczne - jako ostatni z priorytetów - w największym stopniu podkreśla potrzebę powstawania innowacji społecznych. Za główne obszary zainteresowania uznano m.in: zdrowie, zmiany demograficzne, bezpieczeństwo żywnościowe, bezpieczną, czystą i efektywną energię oraz inteligentny, zielony i zintegrowany transport.

Szczególnie istotnym programem w zakresie innowacji społecznych jest ustanowiony na lata 2014-2020 Europejski Program na rzecz Zatrudnienia i Innowacji Społecznych (EaSI). Został on zapoczątkowany działaniami w ramach unijnej perspektywy finansowej na lata 2007-2013. Wówczas obowiązywały trzy oddzielne programy: PROGRESS, EURES oraz instrument mikrofinansowy Progress, które w ramach obecnej perspektywy stanowią osie priorytetowe EaSI (Komisja Europejska, 2014a). Program ten stanowi narzędzie, które ma wspomóc osiągnięcie nadrzędnych celów strategii Europa 2020 - inteligentny, zrównoważony i sprzyjający włączeniu społecznemu rozwój (Ministerstwo Infrastruktury i Rozwoju, 2007). Ma on na celu przede 
wszystkim rozwój i wsparcie innowacji społecznych. Rozporządzenie w tej sprawie podkreśla, że Unia Europejska dostrzega potencjał tego typu innowacji w zakresie zapobiegania ubóstwu, bezrobociu i wykluczeniu społecznemu, a również w promocji zatrudniania i ograniczeniu starzenia się społeczeństwa (Rozporządzenie Parlamentu Europejskiego i Rady (UE) nr 1296/2013). Określa ono pięć głównych zamierzeń programu, jakimi są:

- zwiększenie poziomu współpracy pomiędzy podmiotami publicznymi oraz prywatnymi, a również pomiędzy podmiotami działającymi na rzecz społeczeństwa,

- poprawa warunków pracy, przestrzeganie bezpieczeństwa i higieny pracy, promocja innowacji społecznych,

- zwiększenie poziomu przestrzegania prawa unijnego dotyczącego celów strategii Europa 2020 z uwzględnieniem zasad inteligentnych regulacji,

- podejmowanie działań na rzecz zatrudnienia, zwłaszcza poprzez dostępność rynków unijnych oraz gwarancję mobilności zawodowej,

- promocja zatrudnienia za pomocą zwiększenia dostępu do mikrofinansów, ze szczególnym uwzględnieniem mikroprzedsiębiorstw i osób zamierzających rozpocząć działalność gospodarczą, jak również wzmożone finansowanie firm społecznych.

Instytucje unijne podkreślają, że program w szczególności ma na celu niesienie pomocy osobom w trudnej sytuacji życiowej, promocję równości płci, walkę z wszelką dyskryminacją (m.in. religijną, etniczną, dotyczącą wieku czy orientacji seksualnej), zapewnienie wysokiej jakości zatrudnienia, ochronę społeczeństwa oraz zwalczanie bezrobocia. Na jego realizację przeznaczono 919,5 mln euro, z czego 61\% środków dla osi Progress, 18\% dla EURES oraz 21\% na rozwój przedsiębiorczości społecznej i mikrofinansowania.

Szczególnym zadaniem w ramach osi Progress jest prowadzenie badań i eksperymentowanie w zakresie polityki społecznej oraz polityki zatrudnienia, ze szczególnym uwzględnieniem dialogu i wymiany doświadczeń pomiędzy partnerami oraz zainteresowanymi, co wpisuje się w główne założenia programu. Środki są przeznaczone na walkę z bezrobociem, zwłaszcza wśród osób młodych napotykających bariery wejścia na rynek pracy, poprawę jakości i warunków zatrudniania oraz rozwój ochrony socjalnej.

Oś EURES stawia natomiast na działania służące poprawie dostępu do informacji o sytuacji na rynku pracy i zwiększenia ich transparentności, a również rozwój współpracy transgenicznej, mającej przyczynić się do zwiększenia mobilności geograficznej.

Środki przeznaczone na cel ostatniej osi są w dużej mierze przeznaczone dla firm społecznych, udostępniając im instrumenty finansowe oraz mikrofinansowanie, które przyczynia się do poprawy standardów życia osób w trudnej sytuacji życiowej i mikroprzedsiębiorstw.

Duże źródło wsparcia dla powstawania oraz rozwoju innowacji społecznych stanowią również krajowe programy operacyjne finansowane ze środków unijnych. W Polsce bogata oferta finansowania pochodziła z Programu Operacyjnego Kapitał Ludzki (2007-2013). Środki na jego realizację pochodziły w głównej mierze z Europejskiego Funduszu Społecznego. Program obejmował 10 obszarów wsparcia (osi priorytetowych), na wsparcie których przeznaczono sumę 11,5 mld euro (Ministerstwo Rozwoju Regionalnego, 2007).

W ramach obecnej perspektywy finansowej szczególne wsparcie dla omawianego tematu oferuje PO Wiedza Edukacja Rozwój. Całkowita alokacja środków wynosi 5,5 mld euro. Za obszary wsparcia w ramach programu przyjęto:

- Priorytet I: Osoby młode na rynku pracy,

- Priorytet II: Efektywne polityki publiczne dla rynku pracy, gospodarki i edukacji,

- Priorytet III: Szkolnictwo wyższe dla gospodarki i rozwoju, 
- Priorytet IV: Innowacje społeczne i współpraca ponadnarodowa,

- Priorytet V: Wsparcie dla obszaru zdrowia,

- Priorytet VI: Pomoc techniczna.

W przypadku tego programu należy zwrócić uwagę na priorytet IV, którego działania mają na celu zwiększenie poziomu wykorzystania innowacji społecznych w tworzeniu polityk publicznych. Dofinansowanie mogą otrzymać projekty obejmujące zarówno mikro-innowacje jak i makro-innowacje, a także inicjatywy mające na celu zwiększanie wykorzystania nowatorskich rozwiązań, dotąd rzadko używanych (Ministerstwo Rozwoju Regionalnego, 2007).

\section{Podsumowanie}

W literaturze przedmiotu coraz częściej przedmiotem badań są innowacje społeczne. Wzbudzają one również coraz większe zainteresowanie decydentów uważających, że odpowiadają one na nierzadko poważne wyzwania społeczne. Znajduje to swoje odzwierciedlenie więc w działaniach Unii Europejskiej. Przeprowadzone w rozdziale badania wskazują bowiem, iż wprowadziła ona szereg inicjatyw umożliwiających finansowanie nowatorskich projektów, które oddziaływać mają na wybrane grupy społeczne lub całe społeczeństwo. Ich zakres jest coraz szerszy. Ponadto zwiększono również wartość środków finansowych przeznaczonych na wsparcie innowacji społecznych.

Wyniki przeprowadzonych badań stanowią więc wkład w obszar polityki gospodarczej, w części poświęconej pomocy publicznej. Mogą być przedmiotem zainteresowania nie tylko naukowców, lecz również decydentów politycznych. Rozdział poszerza również zakres literatury przedmiotu badającej tematykę innowacji społecznych.

W opracowaniu nie poruszono jednak kwestii oceny skuteczności ww. programów pomocy publicznej. Jest to temat ważny, zwłaszcza w świetle koncepcji zawodności państwa i konieczności pogodzenia działań rynku i rządu. Wskazuje to zatem kierunek dalszych badań, jakie należy podjąć w najbliższej przyszłości.

\section{Literatura}

Bałoń, L. (2015). W stronę innowacji społecznych. Zarządzanie. Teoria i Praktyka, 4(14), 3-10.

Bednarowska, Z. (2015). Desk research - wykorzystanie potencjału danych zastanych w prowadzeniu badań marketingowych i społecznych. Marketing i Rynek, 7, 18-26.

Commission of the European Communities (2007). Communication from the Commission to the Council, the European Parliament, the European Economic and Social Committee and the Committee of the Regions Establishing the guidelines for the second round of the Community Initiative EQUAL concerning transnational co-operation to promote new means of combating all forms of discrimination and inequalities in connection with the labour market "Free movement of good ideas", COM/2003/0840 final. Pobrane z: https://eur-lex.europa.eu/legalcontent/EN/TXT/PDF/?uri=CELEX:52003DC0840\&from=MT (dostęp: 16.05.2019)

Górka, M. (2015). Wybrane poglądy na temat innowacji jako czynnika konkurencyjności podmiotów gospodarczych. Efektywność zarządzania zasobami organizacyjnymi. Prace Naukowo-Dydaktyczne PWSZ im. Stanisława Pigonia w Krośnie, 68, 31-55.

Komisja Europejska (2014a). Europejski program na rzecz zatrudnienia i innowacji społecznych. (EaSI). Komisja Europejska. Pobrane z: https://ec.europa.eu/social/main.jsp?catld=1081\&langld=pl (dostęp: 16.05.2019).

Komisja Europejska (2014b). Horizon 2020 w skrócie. Program ramowy UE w zakresie badań naukowych i innowacji. Luksemburg: Urząd Publikacji Unii Europejskiej. Pobrane z: https://ec.europa.eu/programmes/horizon2020/sites/horizon2020/files/H2020_PL_KI0213413PLN.pdf (dostęp: 15.05.2019). 
Komisja Europejska (2014c). Komunikat Komisji Europa 2020 Strategia na rzecz inteligentnego i zrównoważonego rozwoju sprzyjającego włączeniu społecznemu. Komisja Europejska. Pobrane z: http://ec.europa.eu/eu2020/ pdf/1_PL_ACT_part1_v1.pdf (dostęp: 04.05.2019).

Maślak, E. (2002). J.A. Schumpeter pół wieku później - współczesna recepcja teorii, Ruch Prawniczy, Ekonomiczny i Socjologiczny, 2, 221-232.

Ministerstwo Infrastruktury i Rozwoju (2007). Programowanie perspektywy finansowej 2014-2020 Umowa Partnerstwa. Warszawa: Ministerstwo Infrastruktury i Rozwoju. Pobrane z: www.funduszeeuropejskie.gov.pl/ strony/o-funduszach/dokumenty/umowa-partnerstwa (dostęp: 16.05.2019).

Ministerstwo Infrastruktury i Rozwoju (2019). Szczegółowy opis osi priorytetowych Programu Operacyjnego Wiedza Edukacja Rozwój 2014-2020. Warszawa: Ministerstwo Infrastruktury i Rozwoju. Pobrane z: www.power. gov.pl/strony/o-programie/dokumenty/szczegolowy-opis-osi-priorytetowych-programu-operacyjnegowiedza-edukacja-rozwoj-2014-2020 (dostęp: 23.05.2019).

Ministerstwo Rozwoju Regionalnego (2007). Program Operacyjny Kapitał Ludzki. Narodowe Strategiczne Ramy Odniesienia 2007-2013. Warszawa: Ministerstwo Rozwoju Regionalnego. Pobrane z: http://pokl.mazowia. eu/g2/oryginal/2011_07/1b11885071fd23f2ef796597e44a1964.pdf (dostęp: 16.05.2019).

Oferta programu Horyzont 2020 dla małych i średnich przedsiębiorstw (2019). Krajowy Punkt Kontaktowy Programów Badawczych Unii Europejskiej. Pobrane z: www.kpk.gov.pl/?page_id=11400 (dostęp: 05.06.2019).

Olejniczuk-Merta, A. (2013). Innowacje społeczne. Konsumpcja i Rozwój, 1(4), 21-34.

Program Operacyjny Kapitał Ludzki (2019). O programie. Ministerstwo Rodziny, Pracy i Polityki SpołecznejDepartament Wdrażania Europejskiego Funduszu Społecznego. Pobrane z: www.kapitalludzki.gov.pl/o-programie (dostęp: 16.05.2019).

Rozporządzenie Parlamentu Europejskiego i Rady (UE) nr 1291/2013 z dnia 11 grudnia 2013 r. ustanawiające "Horyzont 2020" - program ramowy w zakresie badań naukowych i innowacji (2014-2020) oraz uchylające decyzję nr 1982/2006/WE. Dz. U. L 347 z 20.12.2013 r., stan prawny na 15.05.2019.

Rozporządzenie Parlamentu Europejskiego i Rady (UE) nr 1296/2013 z dnia 11 grudnia 2013 r. w sprawie programu Unii Europejskiej na rzecz zatrudnienia i innowacji społecznych („EaSI”) i zmieniające decyzję nr 283/2010/UE ustanawiającą Europejski instrument mikrofinansowy na rzecz zatrudnienia i włączenia społecznego Progress. Dz.U. L 347 z 20.12.2013 r., stan prawny na 16.05.2019.

Schumpeter, J. (1960). Teoria rozwoju gospodarczego. Warszawa: Państwowe Wydawnictwo Naukowe.

Słownik języka polskiego PWN (2019). Pobrane z: https://sjp.pwn.pl/szukaj/innowacja.html (dostęp: 01.05.2019).

Wasiluk, A. (2002). Innowacyjność współczesnych przedsiębiorstw. W: W. Kowalczewski (red.). Zarzqdzanie wspótczesnym przedsiębiorstwem (s. 335-355). Warszawa: Wydawnictwo Akademickie DIALOG.

\section{Public aid for social innovations in the European Union - macroeconomic perspective}

Summary: Social innovations are meant to address the needs of society and as such they are a part of the socio-economic development. The purpose of the chapter is to analyse EU funded initiatives, intended for social innovation growth within the European Union. The authors conducted a literature research and analysis of existing solutions using the desk research method. We established that the issues of social innovation are increasingly the subject of scientific research as well as the subject of interest of decision-makers. This is reflected in the activities of the EU institutions. The scope and value of programs aimed at supporting such innovations are increasing. The chapter outcomes contribute to economic policy studies, particularly regarding public aid, as well as extends the scope of literature dedicated to social innovation.

Keywords: social innovations; public aid; European Union

JEL codes: H19, H39, O35

\section{Informacje o autorach}

\section{Magdalena Pilarczyk}

Małopolski Fundusz Ekonomii Społecznej

ul. Rakowicka 14B, 31-505 Kraków

e-mail: magdalenapilarczyk27@gmail.com

\author{
Maciej Woźniak \\ ORCID: 0000-0001-8520-6443 \\ AGH Akademia Górniczo-Hutnicza \\ Wydział Zarzadzania \\ Katedra Ekonomii, Finansów i Zarządzania \\ Środowiskiem \\ ul. Gramatyka 10, 30-067 Kraków \\ e-mail: mwozniak@zarz.agh.edu.pl
}


Źródło finansowania badań: Wydanie publikacji finansowane z subwencji na utrzymanie i rozwój potencjału badawczego AGH Akademii Górniczo-Hutniczej w Krakowie.

\section{Prawa autorskie i licencja / Copyright and License}

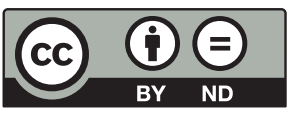

Publikacja na licencji Creative Commons Uznanie autorstwa -

Użycie niekomercyjne - Bez utworów zależnych 4.0 Międzynarodowe (CC BY-ND 4.0)

http://creativecommons.org/licenses/by-nc-nd/4.0/deed/pl

This work is published under the terms of the Creative Commons

Attribution - NoDerivetives International (CC BY-ND 4.0) License http://creativecommons.org/licenses/by-nc-nd/4.0

Wydane przez Uniwersytet Ekonomiczny w Krakowie. Małopolska Szkoła Administracji Publicznej

Published by Cracow University of Economics - Krakow, Poland. Małopolska School of Public Administration of the Cracow University of Economics 